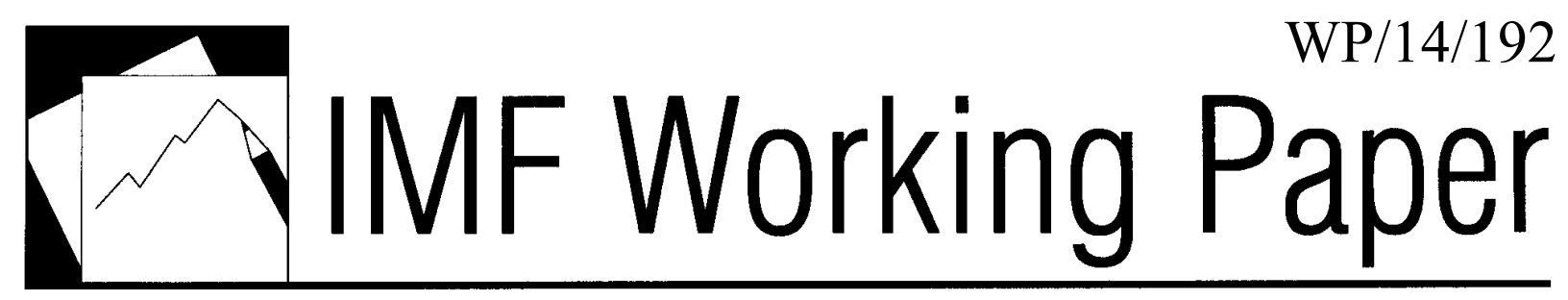

\title{
Public Employment and Compensation Reform During Times of Fiscal Consolidation
}

\author{
Lorenzo Forni and Natalija Novta
}




\title{
IMF Working Paper
}

Fiscal Affairs Department

\section{Public Employment and Compensation Reform during Times of Fiscal Consolidation Prepared by Lorenzo Forni and Natalija Novta}

Authorized for distribution by Julio Escolano

October 2014

\section{This Working Paper should not be reported as representing the views of the IMF. The views expressed in this Working Paper are those of the author(s) and do not necessarily represent those of the IMF or IMF policy. Working Papers describe research in progress by the author(s) and are published to elicit comments and to further debate.}

\begin{abstract}
This paper compiles and compares recent and past measures introduced to contain the public wage bill in a number of emerging and advanced economies to assess their effectiveness in bringing down expenditure in a sustained way. In the aftermath of the Great Recession a number of countries have approved measures on the wage bill as part of fiscal consolidation efforts. These recent episodes are compared to past cases implemented in advanced economies over the period 1979-2009. Findings suggest that public wage bill consolidation episodes pre and post 2009 are similar in many respects. Moreover, typically countries that were able to achieve more sustained reductions in the wage bill have implemented to larger extent structural measures, and/or these measures were accompanied with substantial social dialogue and consensus.
\end{abstract}

JEL Classification Numbers: H1, H5, H6

Keywords: Public sector, wage bill, fiscal consolidation, public reform Authors' E-Mail Addresses: 1forni@imf.org, nnovta@,imf.org 
I. Introduction

II. Trends in Public Sector Compensation and Employment.............................................5

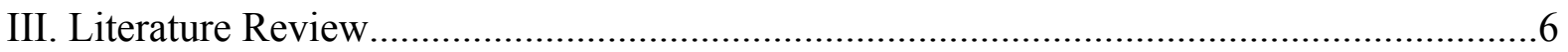

IV. Episodes of Public Employment and Compensation Reform.........................................8

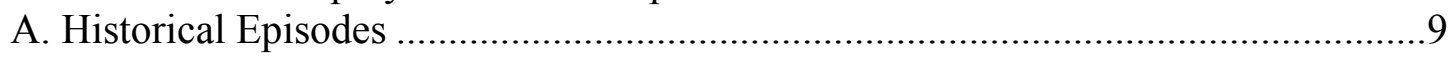

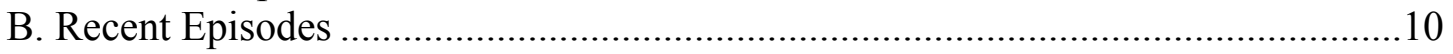

V. Results and Stylized Facts.................................................................................... 11

A. How different are the Historical and Recent Episodes? ......................................11

B. What Types of Measures are Associated with More Sustained Wage Bill

Reductions among Historical Episodes?.......................................................12

C. Preliminary Results on Recent Episodes.........................................................16

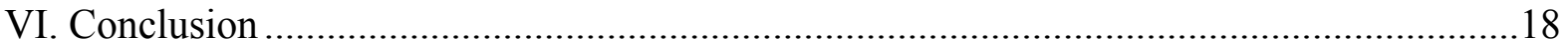

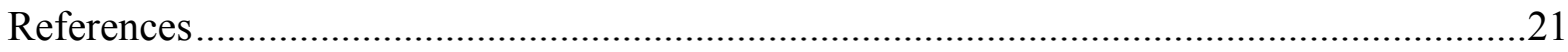

Table

1. Structural Measures and Social Dialogue Across Episodes ............................................12

Figures

1. General Government Wage Bill, Employment, and Average Wage, 2010 .........................5

2. General Government Wage Bill as a Share of GDP and of Expenditures............................6

3. Employment as a Share of Total Populatulation...........................................................6

4. Comparison of Historical and Recent Wage Bill Consolidation Episodes.........................11

5. Structural Versus Non-Structural Measures: Cumulative Change in the Public Wage Bill Ten Years After the First Year of Measures ........................................................13

6. Structural Versus Non-Structural Measures: Cumulative Change in Public Employment .14

7. Social Dialogue Versus Little Social Dialogue: Cumulative Change in the Public Wage Bill Ten Years After the First Year of Measures .........................................................15

8. Social Dialogue Versus Little Social Dialogue: Cumulative Change in Public

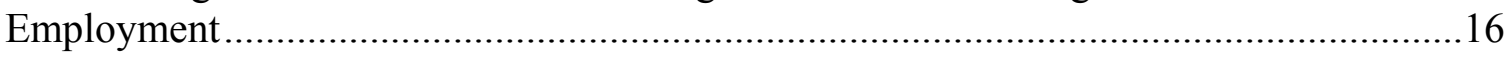

9. Structural Versus Non-Structural Measures, Recent Episodes: Cumulative Change in the Public Wage Bill Ten Years after the First Year of Measures................................17

10. Social Dialogue Versus Little Social Dialogue, Recent Episodes: Cumulative Change in the Public Wage Bill Three Years after the First Year of Measures .....

Box

1. Structural Measures and Social Dialogue

Appendix Tables

1. Historical Episodes of Wage Bill Reduction (1979-2009)............................................19

2. Recent Episodes of Wage Bill Reduction (2009-13) ....................................................20 


\section{INTRODUCTION ${ }^{1}$}

The goal of this paper is to shed light on the successes and failures of past public wage bill consolidations and offer lessons for the wage bill consolidation episodes that are currently taking place in the aftermath of the Great Recession. The paper documents episodes of wage bill consolidation during the periods 1979-2009 and 2009-present, classifies the discretionary measures taken by type (whether they included action on the average wage and/or employment; whether they were one-off or more structural in nature; the extent to which they involved consultations and consensus building). Finally it compares the realized public wage bill reductions.

Currently, many advanced and emerging economies, pressed by large consolidation needs in the aftermath of the Great Recession, are introducing measure to contain the public wage bill. Especially countries in advanced and emerging Europe, that historically have large governments and that recorded high deterioration in fiscal positions, are acting to reduce public employment and wages. But also large advanced countries such as Japan and the United States have recently introduced measures to contain the wage bill as well. The paper aims at offering some lessons from past episodes by assessing which types of past measures have been associated with more persistent reductions in expenditure and which other instead have led either to minor savings or instead have been quickly reversed.

The public wage bill is typically a major target during fiscal consolidations. To a large extent this is due to the fact that expenditure on wages and salaries of public employees represents a significant share of the budget. As a share of total government expenditures, the wage bill reaches on average about 20-25 percent in AEs and EMEs, while it is almost 30 percent in LICs (Figure 1). As a share of GDP, it is on average about 10 percent in AEs, and between 5 and 10 percent in EMEs and LICs. Public employees represent about 7-8 percent of the total population in AEs, and about 5 percent of the population in EMEs and LICs. ${ }^{2}$ In addition to the size of the public wage bill as a share of expenditures, there are other reasons why it has been a prominent target during fiscal consolidations. Especially during crises, many other expenditure items are difficult to cut quickly (e.g., interest, pension, and health expenditures), leaving public wages, together with transfers, as the items that the fiscal authorities have most control over. Moreover, in many of the countries in Europe that are adjusting, the existence of a positive government wage premium relative to the private sector ${ }^{3}$

\footnotetext{
${ }^{1}$ We are very grateful to Julio Escolano and Marta Ruiz-Arranz for providing guidance, to participants in an FAD seminar for their comments, to Chris Faircloth who originally compiled the country level data for the more recent episodes and to Ethan Alt for excellent research assistance.

${ }^{2}$ For definitions and criteria for assessing government employment and compensations see Clements and others (2010).

${ }^{3}$ For evidence on the public sector wage premium in the euro area, see Giordano and others (2011); and more broadly on European countries, see de Castro, Salto, and Steiner (2013).
} 
and, in some cases, the large increase in the wage bill in the run-up to the crisis, were important contributing factors.

Containing public wages can also have important non-fiscal effects on the economy. For example, public wages might affect private wages (European Commission, 2014), thereby helping internal devaluation efforts and improving competitiveness. For this reason, even countries that are not pressed by immediate consolidation needs might choose to reform the public sector and contain the public wage bill.

Finally, due to demographic trends, there will be pressures to increase the provision of health and education in advanced and low income economies, respectively. The government wage bill is a key input in the provision of health and education - currently, the government wage bill represents about 30 and 60 percent of government spending in health and education, respectively, in advanced economies (IMF, April 2014 Fiscal Monitor). This will likely increase the pressure on public finances, especially in low income and some emerging markets.

\section{Our main findings are as follows:}

- Implementation of structural measures, as opposed to one-off measures such as temporary wage or hiring freezes (see Box 1), has been in the past associated with larger and more sustained reductions in the public wage bill as a share of GDP.

- Prior to the Great Recession, countries that were able to create a consensus on the need for reforms and/or negotiated reductions in the public wage bill through social dialogue achieved larger and more permanent reductions.

- Historical (1979-2009) and recent (since 2009) episodes of public wage bill reduction are similar in many respects, especially the frequency with which measures targeted the average wage vs. the number of employees. The main difference is that there has been less social dialogue in the recent episodes.

- In the recent episodes, structural measures again seem to produce larger and more sustained reductions in the public wage bill, although it is too early to make definitive statements.

The remainder of the paper is structured as follows. Section II quickly reviews trends in public sector compensation and employment, Section III provides a literature review of public sector reforms, Section IV explains our data collection exercise, Section V presents results and Section VI concludes. 


\section{Trends in Public Sector Compensation and Employment}

Figure 1 compares the public wage bill for economies at different levels of development. ${ }^{4} \mathrm{We}$ see that the public wage bill is the highest for advanced economies, at around 10 percent of GDP in 2010. In contrast, the public wage bill in emerging market economies and low income countries is lower, at about 6 and 7 percent of GDP.

Figure 1. General Government Wage Bill, Employment, and Average Wage, 2010

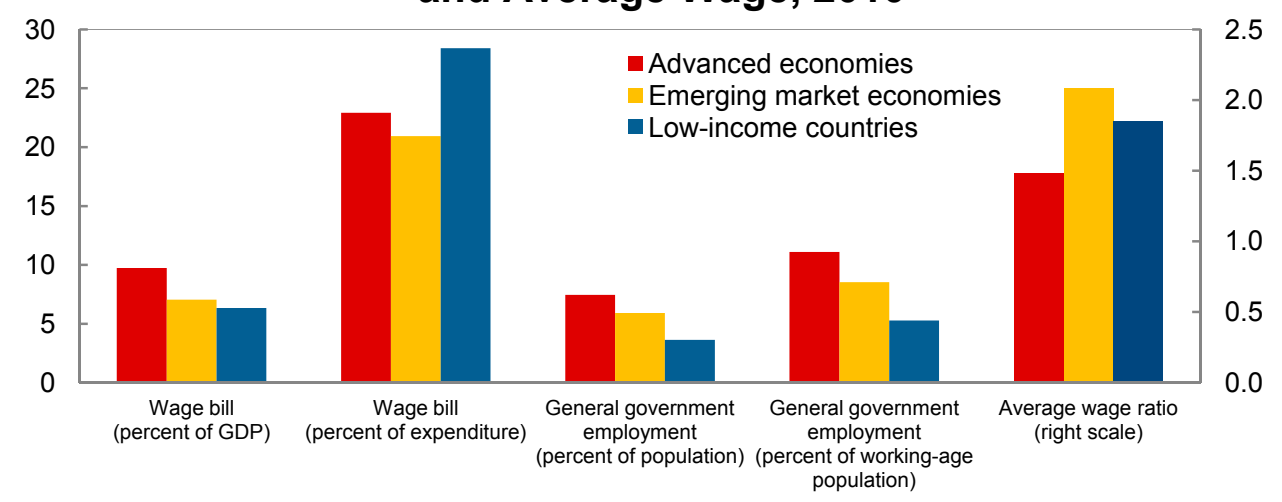

Sources: International Labour Organization; Eurostat; Mauro and others (2013); and IMF staff estimates.

Note: Average wage ratio is defined as the average wage of the general government sector divided by that of the entire economy. Figures for general government employment refer to 2008 data.

While the general government wage bill as a share of GDP is generally the lowest in low income economies, it has been on the rise over the past decade, as shown in Figure 2. To some extent this is expected as low income countries increase the provision of necessary public services, especially health and education. However, emerging market economies tend to face similar demographic challenges but have managed to maintain relatively stable expenditure on the public wage bill.

Looking at the public wage bill as a share of general government expenditures, two key points emerge. First, low income countries tend to spend more on the public wage bill as a share of overall general government expenditures (Figure 1), but this share has been volatile over time (Figure 2). Second, in emerging and advanced economies the public wage bill as a share of general government expenditures is relatively similar (Figure 1), with a tendency of decline over the past decade (Figure 2).

Figure 3 shows that public employment as a share of total population is quite stable over time, both in advanced and in emerging economies. This is consistent with the fact that the public wage bill has been stable over time for these two types of economies. For low income

\footnotetext{
${ }^{4}$ Our wage bill data refer to the general government and were taken from the IMF World Economic Outlook database, Eurostat, AMECO and occasionally IMF country teams.
} 
countries, however, there is insufficient data on public employment over time to make an assessment on whether increases in the public wage bill as a share of GDP are due to increased hiring. This has certainly been the recent tendency in some of the Arab Countries in Transition.

\section{Figure 2. General Government Wage Bill as a Share of GDP and of General Government Expenditures}
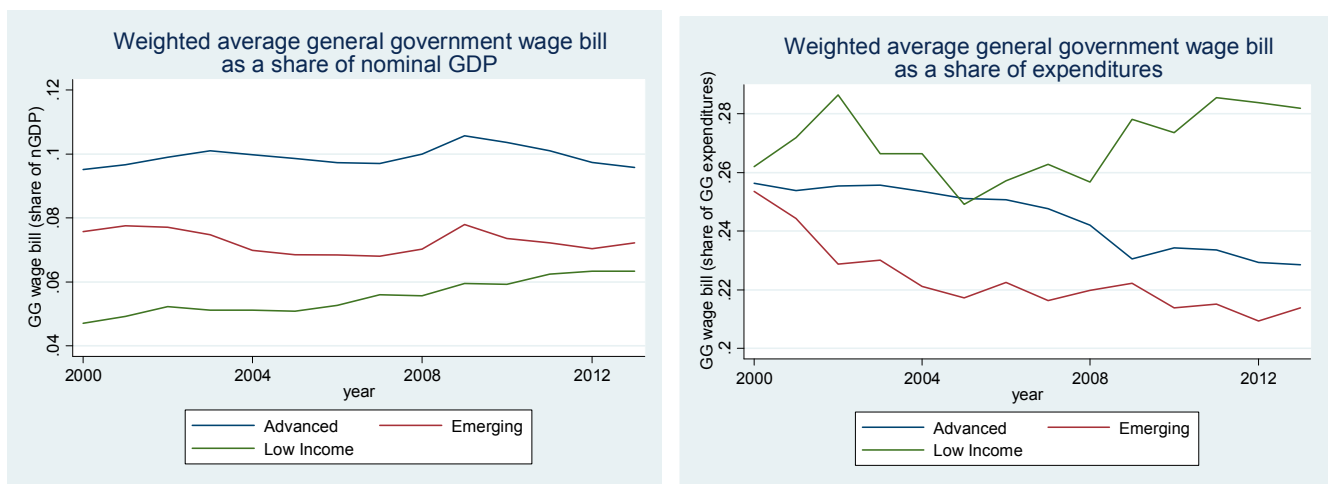

Sources: Eurostat; IMF World Economic Outlook; Mauro and others (2013); and AMECO. Weighted average is calculated using nominal GDP in U.S. dollars.

Figure 3. Employment as a Share of Total Population

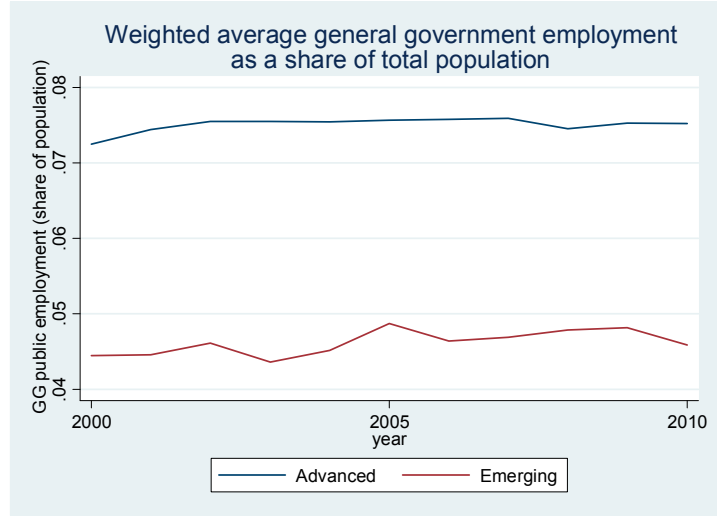

Sources: International Labour Organization and World Development Indicators.

Note: Graph excludes Japan, Russia, and Indonesia because of incomplete data for individual years.

\section{LiterATURE REVIEW}

There are a large number of studies that have addressed different aspects of public employment, although rarely looking at fiscal consolidation episodes as we do in this paper. Without the ambition of being exhaustive, we have identified three broad areas that are related to our work: (i) civil service reforms (often with a focus on emerging and developing economies); (ii) the public wage premium (with more work done on advanced economies, likely because of data availability); and (iii) the interrelations between public sector hiring and wage policies and the private sector labor market. 
Regarding the first point, Nunberg and Nellis (1995) and World Bank and IMF (2002) discuss civil service reform programs in many low-income countries with World Bank and IMF programs. They report that a number of emerging and developing economies initiated comprehensive civil service reforms during the 1980s and 1990s, with mixed success. Many of these reforms were initiated in response to fiscal imbalances, but they also sought to improve accountability and the quantity and quality of public services provided. Three main lessons emerge from these early reforms. First, emergency measures, such as temporary wage and hiring freezes, tend to have only short-term effects, if any. Second, long-term reforms that might yield substantial results typically are politically difficult to implement (World Bank and IMF, 2002; Clements and others, 2010). Some successful reform efforts included targeting on the basis of skills and age along with compensation packages that assisted with the reallocation of the affected government workers. These reforms were accompanied by productivity gains in certain areas, including tax administration and public enterprises, but tended to be financially costly (Haltiwanger and Singh, 1999). Third, reforms in the wage bill should be coordinated with reforms in other areas, especially in laborintensive health and education. Early in the first decade of the 2000s, the use of "wage bill ceilings" in the absence of effective payroll management systems in some low-income countries may have impeded the hiring of adequate workers in these social sectors (Fedelino, Schwartz, and Verhoeven, 2006).

A second strand of literature has focused on the "public wage premium," that is the positive gap in public employees' compensations after controlling for different composition and skill levels between the public and the private sectors. European Commission (2014) presents a comprehensive review on this topic. With reference to European countries, Giordano and others (2011) report evidence on a selection of euro area countries, while de Castro, Salto and Steiner (2013) present evidence for most European countries. In general, the evidence shows the existence of a significant public wage premium, usually higher at the lower levels of the pay-scale and for women. There are also considerable differences across countries. For example, the premium was particularly pronounced in some smaller European countries before the crisis. Regarding EMEs and LICs, the evidence that we have reported show that they tend to spend less on the public wage bill as a share to GDP, but they also have lower levels of public employment (Figure 1 and 2). Together, this leads to typically higher average public wages as compared to per-capita GDP. However, this is only suggestive as the comparison does not control for the different composition and skill characteristics of workers in the public and private sectors.

Finally, a number of papers have addressed the issue of the interrelations between public sector employment and wage policies and the private sector labor market. Again, European Commission (2014) provides a comprehensive literature review also on this issue. In general there is considerable evidence that public compensations have an effect on private compensations. Recent papers on this topic include Perez and Schuknecht (2012) and Lamo, Perez, and Sanchez-Fuentes (2013). These papers show that the link is stronger in countries 
where wage bargaining centralization and coordination is high and there are high levels of union membership, while it is weaker in cases of high openness to trade and in the presence of wage indexation. Hence, to the extent that countries are now more open to trade than in the past, the effect of public sector wages on private sector wages could be smaller.

\section{EPisodes of PUblic EMPloyment ANd Compensation Reform}

We consider two sets of wage bill consolidation episodes - historical episodes that took place between 1979 and 2009, and recent episodes that were precipitated by the global financial crisis and the Great Recession. These episodes were typically part of a more broad based fiscal consolidation effort and in some cases lasted several years. Comparing recent and past cases allows us to evaluate the similarities and differences in terms of the types of measures taken and the associated outcomes in the past and present. Appendix Tables 1 and 2 list the country and year(s) corresponding to each episode. We identify 16 historical and 23 recent episodes of wage bill consolidation. Specifics about country sample selection for each group of episodes are discussed at the end of this section.

Episodes of wage bill consolidation are identified based on discretionary measures taken by the government with the aim of reducing the public wage bill. Hence, it is possible to observe countries that have taken measures but have not reduced their wage bill, i.e., the measures taken were ineffective. It is also possible that a country which has reduced the public wage bill as a share of GDP is not an episode we consider. This might happen, for example, if the reduction in the wage bill as a share of GDP is due to high growth in GDP.

Based primarily on IMF Article IV Staff Reports ${ }^{5}$ for each episode of wage bill consolidation, we classify the discretionary measures in several ways. First, we record whether the government introduced measures targeting the average wage or the employment level or both. The most common wage measure is a wage freeze, or occasionally, a wage cut. In addition, wage measures might include reforming the bargaining model for public wages, changing the compensation grid, changing the public wage indexation rule or introducing pay for performance rules. Employment measures might include hiring freezes, attrition rules, or abolishing positions and/or closing down certain government agencies.

Second, we differentiate between short-term measures and structural measures (see Box 1), both of which can affect compensation and/or employment. A standard short-term measure is

\footnotetext{
${ }^{5}$ Other sources include OECD Public Sector Compensation in Times of Austerity (2012), IMF country teams, IMF Recent Economic Developments, and Stability and Convergence Programmes for select European countries. For these episodes, data on the general government wage bill are Compensations of Employees from Eurostat. Data on the numbers of General Government Employees are from Eurostat NACE Rev. 1.1 categories L, M and N (Public Administration and defense, Health and social work and Education, respectively). Due to data availability, for Canada and Ireland we use General Government Employment data from ILO Laborsta.
} 
a one-off wage freeze - it is designed to be temporary and address immediate needs of the government. On the other hand, structural measures tend to be longer term and are often aimed at improving the efficiency of the public sector. Of the measures mentioned above, structural measures would include: reforming the bargaining model, compensation grid, and public wage indexation rule; introducing pay for performance rules; and abolishing positions or closing down certain government agencies. For more detailed examples, see Box 1.

\section{Box 1. Structural Measures and Social Dialogue}

Examples of structural measures on public wage formation and hiring include the following:

- Reassessing employment level adequacy might require increasing working hours (Portugal, 2009-13, Spain, 2011) or reducing overtime, depending on needs (Greece, Ireland, 2009-12); closing certain government agencies (Greece, 2009-12); or reallocating positions across departments.

- Outsourcing noncore functions if these functions can be provided more efficiently by the private sector (United Kingdom, 1994). Noncore functions such as transport, mail, cleaning, and maintenance are potential candidates for outsourcing.

- Tightening the link between pay and performance can help connect wage increases to individual and organizational performance and create incentives to improve efficiency and productivity (Ireland, 2011). ${ }^{1}$ Linking pay to performance might also require simplifying and decompressing the salary structure (Latvia, 2008-10).

- Spending reviews are organizational audits of the functions of government agencies that attempt to determine the optimal organizational arrangement for government tasks. They provide the basis for defining specific measures to be implemented and can identify areas of duplication and overlap. Such reviews have been used in Canada in 1991; the United Kingdom in 1994, 2010, and 2013; and Portugal in 2013, among others.

Different vehicles have been used to foster social dialogue:

- Public information campaigns are a useful tool for informing employees early on of the detailed administrative and financial aspects of the reform. The general public should also be made aware of the objectives of reforms to defuse opposition while securing its support (Canada, 1991-92).

- Consultation within the public administration should allow staff from different parts of the administration to be involved in the reform effort (Portugal, 2013).

- Negotiations with unions can help the government and social partners reach agreement on comprehensive reforms (Austria, 1996-97; Italy, 1993-95; the Netherlands, 1984-86; Ireland, 2010). ${ }^{2}$

${ }^{1}$ For a discussion of strengths and weaknesses of performance related to pay in the public sector, see OECD (2005).

${ }^{2}$ See Blanchard, Jaumotte, and Loungani (2013) for a discussion of the critical role of trust between the unions and the government in recent labor market reforms, and how it has affected the success of these reforms.

Third, we record whether measures were taken with "high" or "low" level of social dialogue. The extent of social dialogue depends on the extent of open negotiations with unions, communication with private sector employers/trade unions, a public communication strategy or some other explicit effort to try to achieve social consensus and justification for wage bill 
measures taken. Note that this is not a measure of social consensus, but rather of the existence of some action taken with the intention to reach social consensus. Specific country examples are given in Box 1.

\section{A. Historical Episodes}

In Appendix Table 1 we present 16 historical episodes of wage bill consolidation, identified from the set of fiscal consolidation episodes in Devries and others (2011). Devries and others (2011) consider a set of 17 OECD economies from 1979 to 2009 and identify cases of fiscal consolidation motivated by a desire to reduce the budget deficit, rather than respond to cyclical conditions. The fiscal policy measures recorded in Devries and others (2011) were collected from contemporaneous policy documents, such as Budget Speeches, Budgets, central bank reports, IMF Staff Reports, IMF Recent Economic Developments reports, and OECD Economic Surveys. ${ }^{6}$

From the full set of fiscal consolidation episodes of Devries and others (2011), we identify the subset where fiscal plans included measures on the wage bill. Within this subset, we code whether countries took wage or employment measures, whether the measures were shortterm or structural, and whether they included social dialogue.

The historical episodes span a long period of time. Appendix Table 1 provides a brief account of why the measures were taken. For example, measures on the wage bill have often been introduced when there was a need to rein in inflation, as in the run-up to the euro adoption in the mid 1990s (Austria, Belgium, Germany, Italy, Spain) or in response to the ERM 1992 crisis (Italy, the United Kingdom). The stagflation induced by the oil shocks in the late seventies and early eighties also triggered similar adjustments on the public wage bill in a number of countries (Belgium, Germany, Denmark, the Netherlands). Some episodes have been associated with country specific imbalances, as the devaluation episodes in Ireland in the late 1980s. Interestingly, only in a few cases, such as Portugal and Ireland in the 2000s, wage bill measures, which were primarily introduced as a result of the rapidly deteriorating state of the public finances, also explicitly took account of the gap between public and private sector compensation.

\section{B. Recent Episodes}

We identify 23 recent episodes of wage bill consolidation, presented in Appendix Table 2. The set of countries included among the recent episodes was based on two main sources. First, IMF staff provided information about specific wage bill measures taken in respective European IMF member countries. Second, we complemented and checked this list against

\footnotetext{
${ }^{6}$ These data are then used to study the short-term effects of fiscal consolidation on economic activity (see also Romer and Romer, 2010; and Guajardo and others, 2011).
} 
wage bill measures detailed in the OECD Public Sector Compensation in Times of Austerity 2012 report (OECD, 2012). In order to identify structural measures and the extent of social dialogue, we checked the corresponding IMF Staff Report for the Article IV consultation, for each country and year.

All of the recent episodes started in 2009 or after and, in that sense, they were much more homogenous than the set of historical episodes. However, in addition to an unfavorable external environment and global financial pressures associated with the Great Recession, there was variation across countries in their initial size of the public sector. Also, Greece, Ireland, Italy, Portugal, and Spain entered the Great Recession with significantly higher public wage premia than other European countries (see Giordano and others, 2011).

\section{Results ANd Stylized Facts}

\section{A. How Different Are the Historical and Recent Episodes?}

Figure 4 shows that the historical and recent episodes of public wage bill reduction share many characteristics. In fact, despite different circumstances they are very similar in all the dimensions we consider, except the level of social dialogue.

Figure 4. Comparison of Historical and Recent Wage Bill Consolidation Episodes

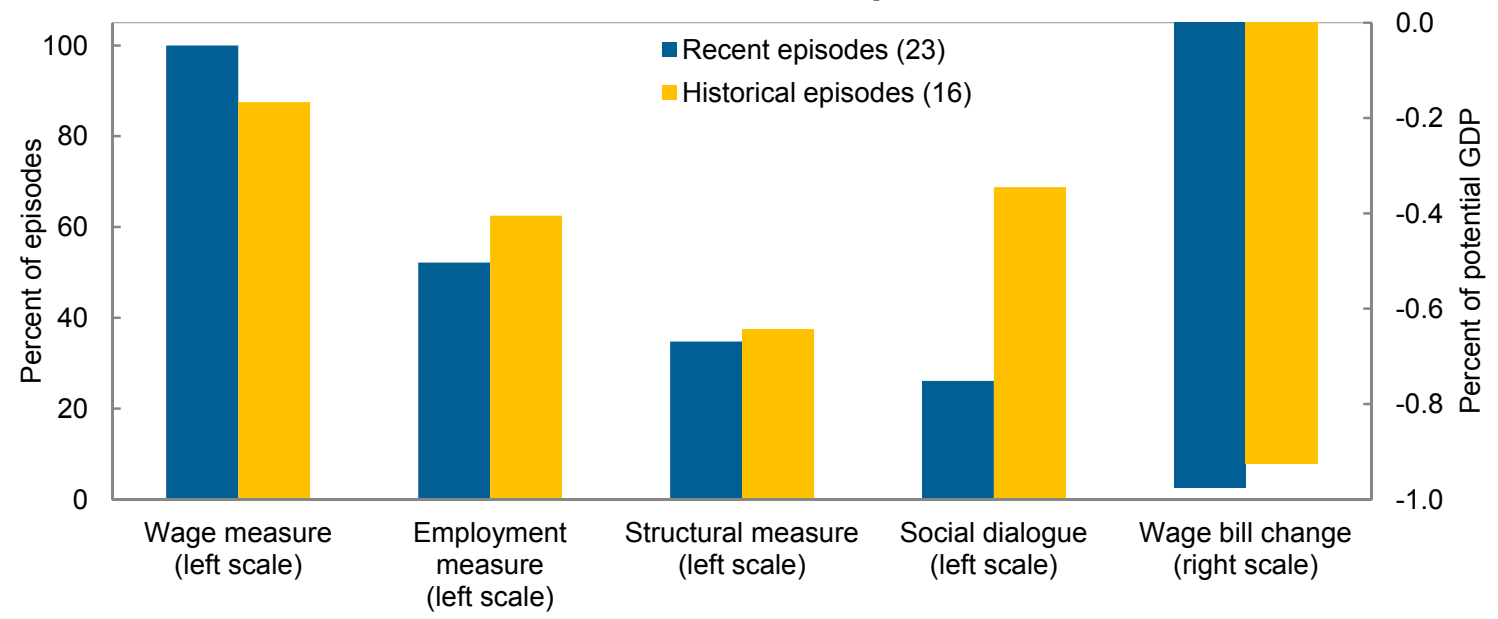

Sources: For historical episodes, Devries and others (2011); IMF Staff Reports for Article IV consultations for various countries and years. For recent episodes, Organisation for Economic Cooperation and Development (Public Sector Compensation in Times of Austerity, 2012); IMF Country teams; and IMF Staff Reports for Article IV consultations. Note: For examples of structural measures and social dialogue, see Box 1 . Wage bill reduction is calculated over five years, following the first year of reform for the historical episodes; it is calculated as the change from 2009-12 for the recent episodes. We use potential GDP whenever available, otherwise nominal GDP.

The most common measure is a temporary wage freeze. All the recent episodes included a wage freeze, or a wage cut. However, even in historical episodes, where pressures to consolidate might have been less immediate, over 80 percent of episodes included wage 
freezes. It should be noted that while a wage freeze is typically temporary, it can indeed have a long-term effect on the wage bill, as long as wages do not grow much faster after the wage freeze is lifted. For example, the Netherlands in the 1980s managed to achieve a substantial and sustained reduction in the wage bill (1.7 percent of GDP) primarily through negotiated and renewed wage freezes. Between 50 and 60 percent of episodes also included measures on the employment level. Employment measures, such as attrition rules or reduced replacement rates for retired workers, typically take time to produce results. Perhaps due to this reason, the overall change in public employment over time tends to be rather smooth, as seen earlier in Figure 3.

Interestingly, the average reduction in the public wage bill is also similar for the historical and recent episodes. ${ }^{7}$ For the historical episodes, the wage bill reduction is the cumulative reduction calculated over five years after the first year of measures. For the recent episodes, due to data availability, the wage bill reduction is calculated as the cumulative reduction from 2009 to 2012. The fact that the average reduction in the wage bill is similar, about 1 percent of potential GDP, despite the shorter time period for the recent episodes is perhaps not surprising given the unprecedented effort by some countries in the recent episodes. However, this average also indicates the general scope for public wage bill reduction and its contribution to reducing the deficit. More detail on individual episodes is reported in the Appendix Tables 1-2.

\section{B. What Types of Measures are Associated with More Sustained Wage Bill Reductions Among Historical Episodes?}

We find that countries that accomplished a sustained reduction in the wage bill tended to rely more on structural measures and/or extensive social dialogue.

Table 1. Structural Measures and Social Dialogue Across Episodes

\begin{tabular}{ccccc}
\hline \multicolumn{5}{c}{ Structural measures } \\
\hline \multirow{3}{*}{ Social } & Hes & No & Total \\
Dialogue & 4 & 7 & 11 \\
& Low & 2 & 3 & 5 \\
& Total & 6 & 10 & 16 \\
\hline
\end{tabular}

Source: Author's calculations.

\footnotetext{
${ }^{7}$ The wage bill measure used in this study is Compensation of Employees from Eurostat, which includes social contributions paid by the employer and the employees and the gross take home pay of the employee. While compensations is the right concept when analyzing fiscal adjustments, as it represents the overall cost for the budget related to public employees, it might not capture the overall adjustment on public employees if additional levies on public employees are introduced. This for example happened in Ireland in 2009, when an additional levy on the gross wage of public employees of seven percent on average (called Pension Related Deduction but not included in social contributions and not counted in the computation of pension benefits) was introduced.
} 
Table 1 indicates that there was a lot of variation in the mix between structural wage bill measures and degree of social dialogue. Namely, it was not the case that countries with structural measures necessarily also engaged in extensive social dialogue (actually the share of episodes with structural measures is almost identical for high- and low- dialogue cases). Likewise, those with extensive social dialogue could sometimes successfully rely on repeated non-structural measures to achieve long-term wage bill reduction, without structural measures.

Figure 5. Structural Versus Non-Structural Measures: Cumulative Change in the Public Wage Bill Ten Years After the First Year of Measures (Percent of Potential GDP)

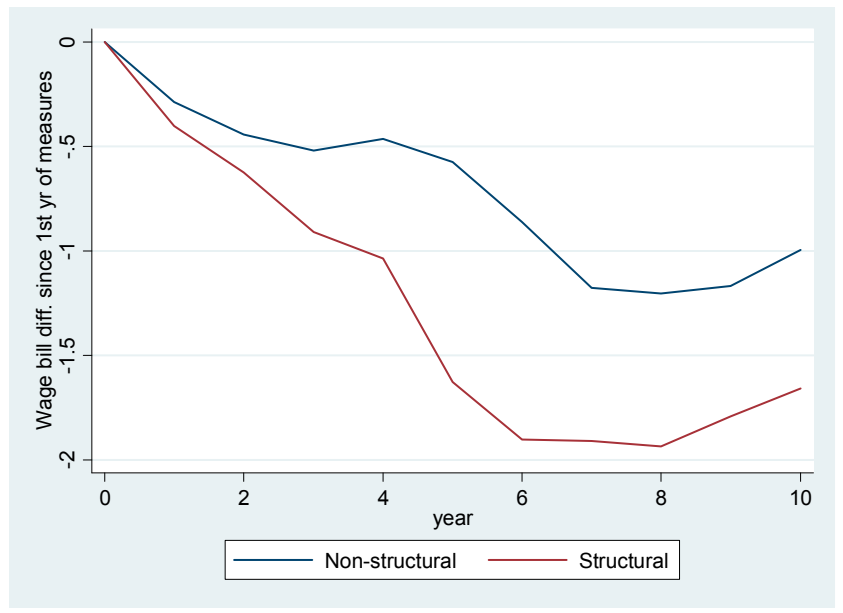

Figure 5 compares the wage bill reduction as a share of potential GDP for episodes with and without structural measures, as detailed in Appendix Table $1 .{ }^{8}$ When the adjustment relied on structural measures the containment of the public wage bill has been larger and more sustained. The difference in the reduction of the public wage bill as a share of GDP is already about 0.5 percent of GDP after four years, which is substantial. Over the course of seven to ten years, the difference can be as large as about 0.7 percent of GDP. These values come from simple averages of the yearly data across the two groups of measures, and given small sample sizes we cannot offer precise confidence intervals. Hence, these should be treated as stylized facts. Nevertheless, it seems that the size of the difference is non-negligible.

\footnotetext{
${ }^{8}$ In the text we focus on absolute changes, i.e. changes in the wage bill over potential GDP, and below on differences in the average public wage divided by per-capita GDP and public employment over population (see Figure 6). Results are very similar if percentage changes are considered. This implies that larger reductions in, for example, the wage bill over potential GDP are associated also with larger percentage reductions. Therefore the analysis holds both for absolute and percentage changes. We have also replicated figure 5 (and figure 7) holding potential GDP fixed at the initial level (when measures were first introduced). While results are qualitatively similar, we observe an increase in the public wage bill as a share of the initial level of potential GDP over time.
} 
It is interesting to see the extent to which a reduction in the wage bill associated with structural measures was due to changes in average wages as opposed to changes in public employment. ${ }^{9}$ To analyze this, we decompose the wage bill into two components: (1) an average public wage component (average wage divided by GDP per capita); and (2) a public employment component (public employment divided by total population).

$$
\frac{w L}{Y}=\left(\frac{w}{Y / P o p}\right)\left(\frac{L}{P o p}\right)
$$

Figure 6 shows the graphs according to this decomposition of the wage bill. We see that episodes with structural measures had a smaller increase in the public employment level as compared to episodes with non-structural measures. In contrast, the average reduction in the average wage was not very different for the episodes with and without structural measures. If anything, in the period six to 10 years after the first year of measures, the average wage (as a percentage of per capita GDP) appears to fall less for the episodes with structural measures. We must stress, however, that the decomposition graphs shown should be interpreted with caution given problems of data availability for public employment. ${ }^{10}$

Figure 6. Structural Versus Non-Structural Measures:

Cumulative Change in Public Employment (Percent of Population) (left) and Average Wage (right) Ten Years after the First Year of Measures
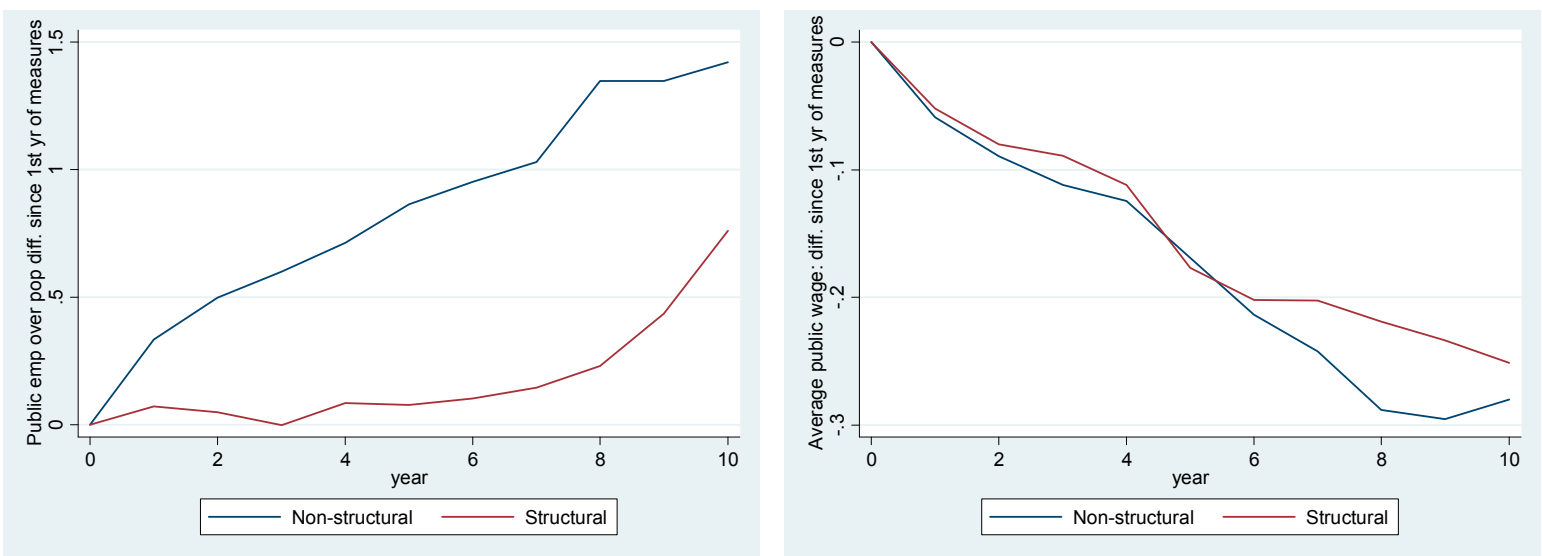

\footnotetext{
${ }^{9}$ Structural measures can be targeting the average wage (i.e. tightening the link between pay and performance), the employment level (i.e. outsourcing) or both (i.e. spending review). Episodes that we code as entailing structural measures often included a combination of them. Moreover, given the limited sample we work with, splitting the episodes with structural measures depending on whether they were targeting the average wage, the employment level or both would leave us with very few observations in each group. That's why we simply look at how the average wage and employment level behaves when structural measures are introduced, regardless of whether these targeted employment or the average wage.

${ }^{10}$ While wage bill data was available for all except one (Germany 1983-84) of our 16 episodes, data on public employment levels are available only for 9 out of the 16 episodes.
} 
Figure 7 compares reduction in the wage bill for episodes that were characterized by substantial social dialogue to those with little social dialogue. We see that in the past, larger and more sustained reductions in the wage bill typically also required broad public support and social partners' involvement. In particular, the difference in the reduction of the public wage bill as a share of potential GDP across episodes with high and little social dialogue is about 0.5 percent of GDP after about five years, similar to the difference between structural and non-structural measures. Over the course of seven to ten years, the difference can be as large as about 1 percent of GDP or more.

There are some notable examples of successful social dialogue. For example, in Austria in 1996/97 the authorities consulted social partners extensively at each stage of the process and secured a lasting agreement, in contrast to a failed attempt in 1995. Canada, after introducing measures to explicitly contain the wage bill at the beginning of the nineties, consolidated the effort with a comprehensive review of federal spending for a "long-lasting structural change in what the government does" and a "fundamental change in how the government delivers programs and services" (1995 Budget, pp. 11-2). ${ }^{11}$ There are commendable recent efforts in Portugal and Ireland to deepen the social dialogue and involve both public employees and general public in discussions and implementation of public expenditure reviews.

Figure 7. Social Dialogue Versus Little Social Dialogue:

Cumulative Change in the Public Wage Bill Ten Years after the First Year of Measures (Percent of Potential GDP)

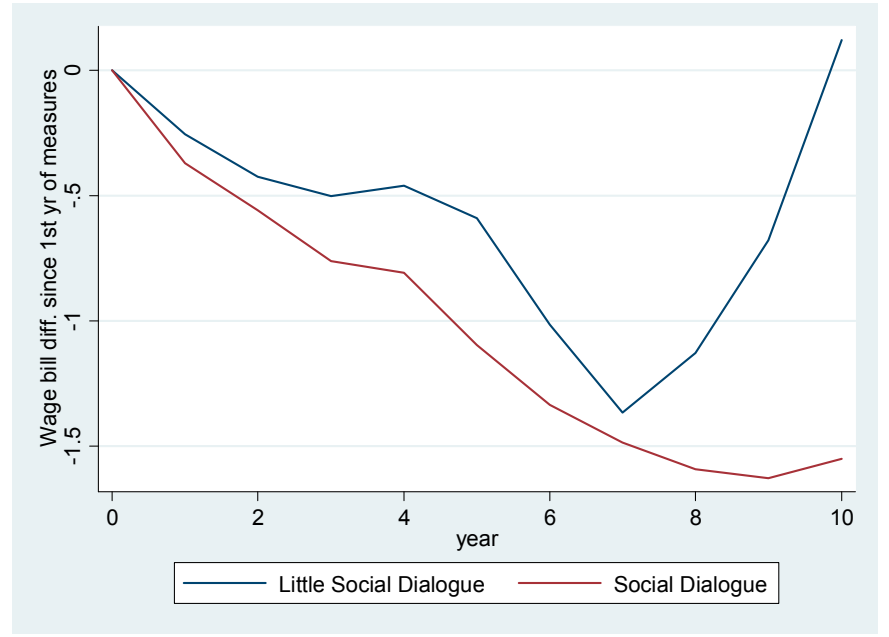

\footnotetext{
${ }^{11}$ Throughout, the Canadian government enjoyed a strong public support. However, it should be noted that the Canadian road was also long and bumpy - the first public expenditure review was initiated in the mid 1980s but it was not until a decade later than these efforts really bore fruit. For a description of the Canadian fiscal adjustment during the nineties see Mauro (2011).
} 
Decomposing the reduction in the wage bill into average wage and public employment as percent of total population, we see that episodes with social dialogue tend to have lower increases in public employment and similar reductions in the average wage. However, these differences are not large.

Overall, our findings suggest that structural measures and/or social dialogue support larger and more sustained reductions in the public wage bill. However, these findings must be taken with caution. First, they should be interpreted more as correlations, rather than causal relationships. In fact, although the wage bill measures that we consider were all aiming at significant budget savings as part of fiscal consolidation episodes, we don't have information on the expected savings from each measure. It might well be the case that countries that counted more on reducing the wage bill to produce budget savings are also those that implemented more structural measures or relied more on social dialogue. Second, our sample sizes are very small, insufficient for finding results with statistical significance. Yet, our hope is that these preliminary findings may open avenues for future research.

Figure 8. Social Dialogue Versus Little Social Dialogue:

Cumulative Change in Public Employment (Percent of Population) (left) and Average Wage (right) Ten Years after the First Year of Measures
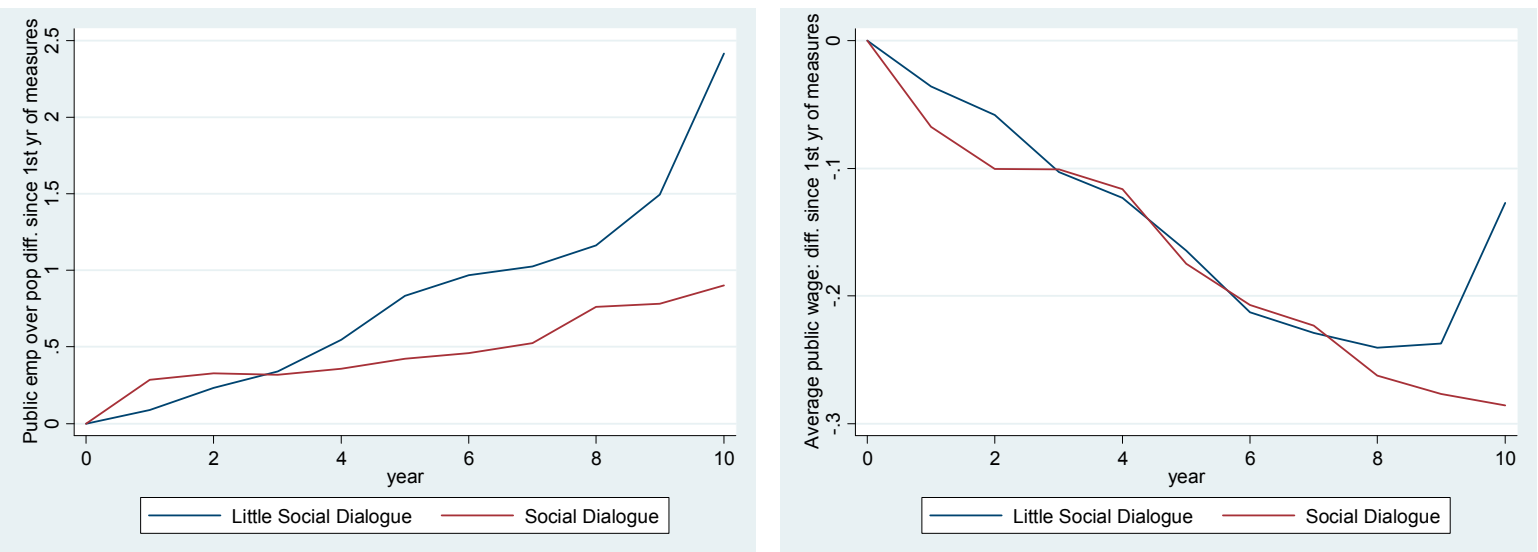

\section{Preliminary Results on Recent Episodes}

It might still be too early to analyze the recent episodes of wage bill reduction over the medium term. For countries that introduced measures in 2009 or 2010 (see Appendix Table 2), we present the graphs in Figures 9 and 10. As in the historical episodes, we calculate the reduction in the public wage bill as a percent of potential GDP, since the first year in which measures were taken. Given wage bill data availability through 2013, we look at the reductions over three years, starting from 2009 or 2010. 
Figure 9. Structural versus Non-Structural Measures, Recent Episodes: Cumulative Change in the Public Wage Bill Ten Years after the First Year of Measures (Percent of Potential GDP)

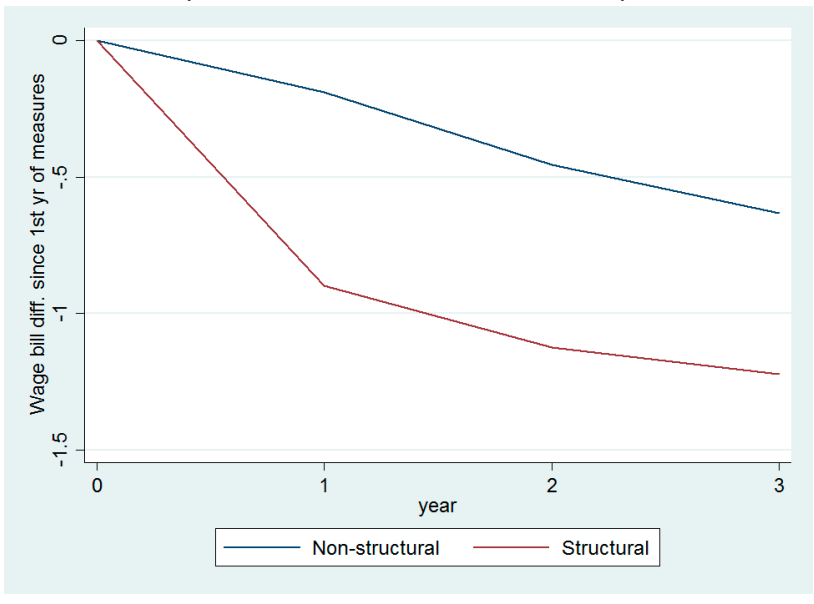

Figure 10. Social Dialogue versus Little Social Dialogue, Recent Episodes: Cumulative Change in the Public Wage Bill Three Years after the First Year of Measures (Percent of Potential GDP)

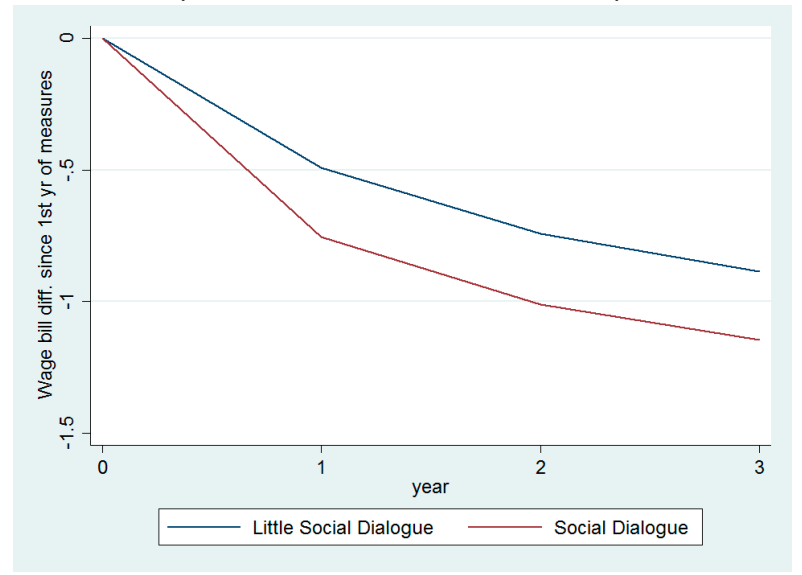

Based on the preliminary results in Figure 9, structural measures seem to be at least as effective as in the past, if not more. Structural measures used in the recent episodes are associated with reduction of close to 1 percent of potential GDP already in the first year after measures were taken. While this is a quicker reduction than in past episodes, the recent crisis has likely required stronger and more urgent action.

In contrast to the historical episodes, there was much less social dialogue in the recent episodes, perhaps due to the lack of time necessary to develop it. We see in Figure 10 that the difference in wage bill reductions between countries with and without social dialogue is not large, at about 0.25 percent of GDP. More time will need to pass before we can make more conclusive assessment of the effectiveness and shortcomings of the recent wage bill measures. 


\section{Conclusion}

The reader should bear in mind that our analysis is based on a limited number of cases and that the coding of the different episodes entailed a certain degree of judgment. Moreover, we assessed the effectiveness of the measures in reducing the public wage bill, as this was their main goal. We did not address the effect of these measures on the efficiency of the public sector or on the provision of public services. As in many countries the real output of the government is still measured from the cost side, this would be a very difficult task.

Overall, our results suggest that structural measures and/or social dialogue support larger and more sustained reductions in the public wage bill. At the same time across-the-board measures, such as wage freezes, may bring temporary budget relief, but they are unlikely to be effective to address longer term consolidation needs. This was the case in historical episodes of wage bill reduction (1979-2009) and it appears to be the case also in the recent episodes.

As governments make progresses in consolidating the fiscal accounts they will have also to accommodate important changes in the composition of public expenditures (for example less expenditure on education and more on health due to aging ${ }^{12}$ ). These additional challenges reinforce the need to approach public employment and compensation reform relying less on temporary and one-off measures and more on longer term structural changes guided by careful assessments of spending needs. Bringing on board the public opinion and implementing these changes in a context of dialogue with the important stakeholders might prove essential.

\footnotetext{
${ }^{12}$ See Clements and others (2012) for estimates regarding the foreseen increase in health expenditures.
} 
Appendix Table 1. Historical Episodes of Wage Bill Reduction (1979-2009)

\begin{tabular}{|c|c|c|c|c|c|c|c|}
\hline Country & Year & $\begin{array}{c}\text { Reason for wage bill } \\
\text { measures }\end{array}$ & $\begin{array}{c}\text { Wage } \\
\text { measure }\end{array}$ & $\begin{array}{c}\text { Staff } \\
\text { measure }\end{array}$ & $\begin{array}{c}\text { Structural } \\
\text { measure }\end{array}$ & $\begin{array}{l}\text { Extent } \\
\text { of social } \\
\text { dialogue }\end{array}$ & $\begin{array}{l}\text { Wage bill } \\
\text { reduction } \\
(\% \text { GDP) }\end{array}$ \\
\hline Austria & 1996-97 & $\begin{array}{l}\text { meet Maastricht } \\
\text { targets; improve } \\
\text { competitiveness }\end{array}$ & Yes & Yes & Yes & High & -2.35 \\
\hline Belgium & 1982 & $\begin{array}{l}\text { improve } \\
\text { competitiveness }\end{array}$ & Yes & No & Yes & High & -1.70 \\
\hline Belgium & 1992, 1994 & $\begin{array}{l}\text { meet Maastricht } \\
\text { targets }\end{array}$ & Yes & Yes & No & High & -0.23 \\
\hline Canada & 1991-92 & reduce fiscal deficit & Yes & No & Yes & High & -2.02 \\
\hline Denmark & 1983-84 & $\begin{array}{c}\text { improve } \\
\text { competitiveness }\end{array}$ & Yes & No & No & Medium & -0.80 \\
\hline Germany & 1983-84 & $\begin{array}{c}\text { economy wide wage } \\
\text { moderation }\end{array}$ & Yes & No & No & Medium & $\cdots$ \\
\hline Germany & $\begin{array}{c}\text { 1995, } \\
1997,2000\end{array}$ & $\begin{array}{l}\text { meet Maastricht } \\
\text { targets; increase } \\
\text { productivity }\end{array}$ & Yes & Yes & No & Medium & -0.33 \\
\hline Ireland & 1982 & reduce fiscal deficit & No & Yes & No & Low & -0.65 \\
\hline Ireland & $1987-88$ & reduce fiscal deficit & Yes & Yes & No & Medium & 0.07 \\
\hline Italy & 1993, 1995 & $\begin{array}{l}\text { reduce fiscal deficit; } \\
\text { macro adjustment } \\
\text { after exit from ERM }\end{array}$ & Yes & Yes & Yes & High & -1.16 \\
\hline Netherlands & $\begin{array}{c}1981 \\
1983 \\
1984-86\end{array}$ & reduce fiscal deficits & Yes & No & No & High & -1.66 \\
\hline Netherlands & 2005 & $\begin{array}{l}\text { reduce fiscal deficit; } \\
\text { improve } \\
\text { competitiveness }\end{array}$ & Yes & No & No & Low & 0.23 \\
\hline Portugal & 2000,2003 & $\begin{array}{l}\text { reduce deficit to SGP } \\
\text { target; high public } \\
\text { employment }\end{array}$ & No & Yes & No & Low & -0.20 \\
\hline Portugal & 2005-07 & $\begin{array}{l}\text { reduce deficit to } \\
\text { SGP's target; high } \\
\text { pub. wage premium; } \\
\text { high pub. } \\
\text { employment }\end{array}$ & Yes & Yes & Yes & Low & -1.37 \\
\hline Spain & 1997 & $\begin{array}{l}\text { meet Maastricht } \\
\text { targets }\end{array}$ & Yes & Yes & No & Medium & -0.80 \\
\hline $\begin{array}{l}\text { United } \\
\text { Kingdom }\end{array}$ & 1994 & $\begin{array}{l}\text { macro adjustment } \\
\text { after exit from ERM }\end{array}$ & Yes & Yes & Yes & Low & -0.92 \\
\hline
\end{tabular}

Note: SGP stands for Stability and Growth Pact. For the definition of structural measures and the extent of social dialogue see section IV and Box 1. The reduction of the wage bill is the cumulative reduction over five years following the first year of measures, as a share of potential GDP, except in case of Canada, Denmark, Spain, and Ireland (1982) where it is expressed as a share of nominal GDP, because potential GDP was not available. Sources: IMF Staff Reports for Article IV consultations for various years. 
Appendix Table 2. Recent Episodes of Wage Bill Reduction (2009-13)

\begin{tabular}{|c|c|c|c|c|c|c|}
\hline Country & Year & $\begin{array}{c}\text { Wage } \\
\text { measure }\end{array}$ & $\begin{array}{c}\text { Staff } \\
\text { measure }\end{array}$ & $\begin{array}{c}\text { Structural } \\
\text { Measure }\end{array}$ & $\begin{array}{c}\text { Extent } \\
\text { of social } \\
\text { dialogue }\end{array}$ & $\begin{array}{l}\text { Wage bill } \\
\text { reduction } \\
\text { (\% pGDP) }\end{array}$ \\
\hline Bosnia & $2012-13$ & Yes & Yes & No & Low & -1.02 \\
\hline Bulgaria & $2010-13$ & Yes & Yes & Minor & Low & -0.95 \\
\hline Croatia & 2009-13 & Yes & No & Medium & Low & -0.06 \\
\hline Cyprus & 2013 & Yes & Yes & Medium & Low & -0.66 \\
\hline $\begin{array}{l}\text { Czech } \\
\text { Republic }\end{array}$ & 2010 & Yes & No & No & Low & -0.57 \\
\hline France & 2011-12 & Yes & Yes & No & Low & -0.13 \\
\hline Greece & 2009-13 & Yes & Yes & Major & Low & -2.87 \\
\hline Hungary & $2010-13$ & Yes & Yes & Medium & Low & -1.48 \\
\hline Ireland & 2009-13 & Yes & Yes & Major & High & -1.12 \\
\hline Italy & $2009-13$ & Yes & Yes & Minor & Low & -0.64 \\
\hline Japan & 2012 & Yes & No & No & Low & $\ldots$ \\
\hline Latvia & 2009-12 & Yes & Yes & Major & Medium & -1.62 \\
\hline Macedonia & $2009-13$ & Yes & Yes & Minor & Low & -0.60 \\
\hline Netherlands & 2012 & Yes & No & No & Low & -0.38 \\
\hline Poland & 2009-13 & Yes & No & No & Low & -0.54 \\
\hline Portugal & 2011-13 & Yes & Yes & Major & High & -3.02 \\
\hline Romania & $2010-13$ & Yes & Yes & Major & Medium & -3.23 \\
\hline Serbia & $\begin{array}{l}2009-10 \\
2012-13\end{array}$ & Yes & No & No & Low & -0.09 \\
\hline Slovakia & 2013 & Yes & No & No & Low & -0.51 \\
\hline Slovenia & $\begin{array}{l}2010 \\
2012-13\end{array}$ & Yes & No & Minor & Medium & -0.63 \\
\hline Spain & 2010-12 & Yes & No & Minor & Medium & -0.86 \\
\hline $\begin{array}{l}\text { United } \\
\text { Kingdom }\end{array}$ & 2011-12 & Yes & No & No & Low & -0.89 \\
\hline United States & 2011-12 & Yes & No & No & Low & -0.66 \\
\hline
\end{tabular}

Note: For the definition of structural measures and the extent of social dialogue see section IV and Box 1. The reduction of the wage bill is the cumulative reduction from 2009 to 2012, as a share of potential GDP. Sources: OECD (Public Sector Compensation in Times of Austerity, 2012), IMF Country teams, IMF Staff Reports for Article IV consultations for various years. 


\section{REFERENCES}

Blanchard, Olivier J., F. Jaumotte, and P. Loungani, 2013, "Labor Market Policies and IMF Advice in Advanced Economies during the Great Recession," IMF Staff Discussion Note 13/02 (Washington: International Monetary Fund).

Clements, B., S. Gupta, S. Tareq, and I. Karpowicz, 2010, "Evaluating Government Employment and Compensation," IMF Technical Notes and Manuals 10/15 (Washington: International Monetary Fund).

Clements, B.J., D. Coady, and S. Gupta, eds., 2012, The Economics of Public Health Care Spending in Advanced and Emerging Economies (Washington: International Monetary Fund).

de Castro, F., M. Salto, and H. Steiner, 2013, "The Gap Between Public and Private Wages: New Evidence for the EU," EC Economic Papers 508 (Brussels: European Commission).

Devries, P., J. Guajardo, D. Leigh, and A. Pescatori, 2011, “A New Action-based Dataset of Fiscal Consolidation," IMF Working Paper 11/128 (Washington: International Monetary Fund).

European Commission (EC), 2014, “Government Wages and Labour Market Outcomes,” EC Occasional Papers 190 (Brussels).

Fedelino, A., G. Schwartz, and M. Verhoeven, 2006, “Aid Scaling Up: Do Wage Bill Ceilings Stand in the Way?” IMF Working Paper 06/106 (Washington: International Monetary Fund).

Giordano, R., D. Depalo, M. Coutinho Pereira, B. Eugène, E. Papapetrou, J. J. Pérez, L. Reiss, and M. Roter, 2011, "The Public Sector Pay Gap in a Selection of Euro Area Countries,” ECB Working Paper No. 1406 (Frankfurt: European Central Bank).

Guajardo J., D. Leigh, and A. Pescatori, 2011, "Expansionary Austerity: New International Evidence,” IMF Working Paper 11/158 (Washington: International Monetary Fund).

Haltiwanger, J., and M. Singh, 1999, "Cross-country Evidence on Public Sector Retrenchment," The World Bank Economic Review, Vol. 13, No.1, pp.23-66.

Lamo, A., J.J. Perez, and L. Schuknecht, 2012, "Public or Private Sector Wage Leadership? An International Perspective," Scandinavian Journal of Economics, Vol. 114, No. 1, pp. 228-44. 
Mauro, P., R. Romeu, A. Binder, and A. Zaman, 2013, “A Modern History of Fiscal Prudence and Profligacy," IMF Working Paper 13/5 (Washington: International Monetary Fund).

Nunberg, B., and J. Nellis, 1995, “Civil Service Reform and the World Bank," World Bank Discussion Papers, 161 (Washington: International Bank for Reconstruction and Development/World Bank).

Organisation for Economic Co-operation and Development (OECD), 2005, PerformanceRelated Pay Policies for Government Employees (Paris).

_ , 2011, "Getting It Right: Restructuring the Government Workforce," in Public Servants as Partners for Growth: Toward a Stronger, Leaner and More Equitable Workforce (Paris).

— 2012, Public Sector Compensation in Times of Austerity (Paris).

Perez, J.J., and A.J. Sanchez, 2011, "Is There a Signaling Role for Public Wages? Evidence of the Euro Area Based on Macro Data," Empirical Economics, vol. 41, No. 2, pp. 421-45.

Romer, C. D., and D. H. Romer, 2010, "The Macroeconomic Effects of Tax Changes: Estimates Based on a New Measure of Fiscal Shocks," American Economic Review, Vol. 100, No. 3, pp. 763-801.

World Bank and International Monetary Fund (IMF), 2002, Civil Service Reform: Strengthening World Bank and IMF Collaboration (Washington). 